\title{
Physical Activity as a Fundamental Contribution to the Paradigm of Good Living in Children and Adolescents
}

\author{
Vinicio Bonilla Carrión*, David Bonilla Cervantes, Flor Garcés Mancero and Julio Samaniego Salas \\ Department of Security and Defense, University of the Armed Forces-ESPE, South America
}

*Corresponding author: Vinicio Bonilla Carrión, Department of Security and Defense, University of the Armed Forces-ESPE, South America

\begin{abstract}
ARTICLE INFO
Received: 慧 February 01, 2019

Published: 幽 February 12, 2019

Citation: Vinicio Bonilla C, David Bonilla C, Flor Garcés M, Julio Samaniego S. Physical Activity as a Fundamental Contribution to the Paradigm of Good Living in Children and Adolescents. Biomed J Sci \& Tech Res 14(3)-2019. BJSTR. MS.ID.002551.
\end{abstract}

\begin{abstract}
Education as a fundamental axis of the development of peoples poses an integral education of the human being. When speaking of integral formation, it must be recognized that it must be based on a human body properly developed and above all with an excellent health in order to be able to exercise all the activities that, as a living being, must perform them. This article highlights the disadvantages caused by the lack of physical activity of children and adolescents and how it then impacts on school, work, social and economic performance. When problems deepen and manifest themselves through diseases and social problems, solutions are sought instead of having been prevented. This research seeks to prevent through physical activity many disorders that are presented and that are reflected especially in the field of health. The human brain needs a healthy body to be able to perform optimally, and it is physical activity that presents this great help. Throughout history the survival of the human species has depended on hunting or gathering food, occupations that required prolonged and intense physical activity. For which we proceeded to collect data of the present work was obtained the permission and the collaboration of Mr. Advocate Cesar Montenegro, Rector of the Educational Unit "John F. Kennedy" of the city of Salinas. The work was carried out with a total of 25 among the children of the sixth year of basic education, before their beginning was recorded the weight and height of the students, and through the Body Max Index (BMI) the first data. Among the most representative results is that of 25 students of whom 10 are in the range considered as obesity, 4 in the overweight range, 6 in the range considered normal and 5 students who are in the low weight ran.
\end{abstract}

Keywords: Body Mass Index; Students; Weight; Age

\section{Introduction}

Good living is a new development model, a vision of the world centered on the human being as a fundamental part of the natural and social environment. Good living considers education as an essential component since it allows the development of human potentialities and therefore guarantees equal opportunities for all people. Sport must be the fundamental ally of the development strategy of a country, especially Ecuador. Physical, sports and recreational activity provides benefits in mental and physical health, allows humans to free themselves from the tendency to sedentary lifestyle and obesity, mainly school age. In Ecuadorian education, more than 2 hours of physical education and the possibility of some schools to hire sports coaches to form their own teams, there is no incentive for more knowledge about sports, their values, techniques, skills and rules of the game. It should be mentioned that students are not taught to maintain a healthy life, that is: how to eat, what activities to perform, how to occupy free time in a constructive and profitable way.

One of the main lessons should be sports practice as a means and pedagogical aid, as a method of learning skills, skills and values and even as an objective to combat poverty, crime, and stop the advance and consumption of drugs. The present work was carried out in the Educational Unit "John F Kennedy" of the city of Salinas Province of Santa Elena. In this Educational Unit it is evident that there are primary students who exceed their weight. 
According to [1] Physical activity is very important for the prevention and attenuation of osteoporosis. Osteoporosis is a frequent disease in modern societies. In 1991, osteoporosis was defined as a systemic disease characterized by low bone mass, resulting in an increase in bone fragility and, therefore, in the risk of fracture. To reduce the risk of osteoporosis, it is recommended to perform regular jogging or walking exercise since the impact of the feet with the ground produces a moderate micro trauma, which is reinforced during rest and prepares the body for a new activity, of this shape the bones increase their density and their resistance to traumatisms. According to [2] physical health is a physiological state and a reflection of the physical, mental and social well-being of the person. It is a term that is broader than a simple absence of disease. Physical health is a level of protection against chronic diseases and the foundation for the development of sports activities.

\section{Materials and Methods}

The John F Kennedy Educational Unit is located in the city of Salinas, Parish José Luis Tamayo, has large and adequate classrooms for the development of the teaching-learning process, the average student per classroom is 25 , all decent have third level degrees and they are trained for the assigned work. The establishment has laboratories of English, Computing, Physics, Chemistry and Natural Sciences. It has a bar, in which students acquire their treats to appease hunger, this is where one of the main problem sites of this work is located.

Although the bar has fruit for student consumption, they do not like this type of food, and there are ways to consume products made from fried and oversaturated fats. There is a total ignorance of the damage caused by this type of food, because neither parents, teachers, nor authorities do anything to change these bad eating habits. To this problem is added the lack of physical activity of the students, physical culture classes is limited to two sessions of 40 minutes per week and if these minutes are deducted the time required for the change of clothing, and subsequent cleaning, the Actual work time is estimated at 30 minutes.

In order to carry out the present work, the permission and collaboration of Mr. Abogado Cesar Montenegro, Rector of the Educational Unit "John F Kennedy" of the city of Salinas, was obtained. The work was carried out with the children of the sixth year of basic education, before the start the weight and height of the students were registered, and through the Body Max Index (BMI) the first data were made.

\section{Body Mass Index BMI Body Mass Index BMI}

The body mass index indicates the nutritional status of the person, taking into account two basic factors: their weight and height. Its calculation indicates the value by which a person is said to be below, within or exceeded the weight established as normal for their physical size. The mathematical equation that allows to obtain its value is the following:

\section{$\mathrm{BMI}=\frac{P E S O(\mathrm{~kg})}{(E S T A T U R A)^{2}(\mathrm{~m} .)}$}

It is considered that a nutritional status is good, when the BMI value is within the specified range in values ranging from 20 to 25 .

\section{Analysis of Results}

In the work done with the children of the sixth grade, it was found that the children had a slight decrease in their initial weight, but there was an increase in their height. This provides the satisfaction that the overweight index did decrease, although not in the desired results. It should be emphasized that the weight reduction process takes place after months and in some cases, for years, so that children are expected to feel motivated to practice sports and in the same way their parents and teachers (Figure 1). The analysis of the muscle mass index was carried out, which is the one that presents the most ease of use. In the initial analysis of the 25 children of the sixth year of Basic Education, it was detected that: 1 child is obese, 6 children were overweight, 13 children with a weight considered normal, 5 have a weight considered as a low weight (Table 1).

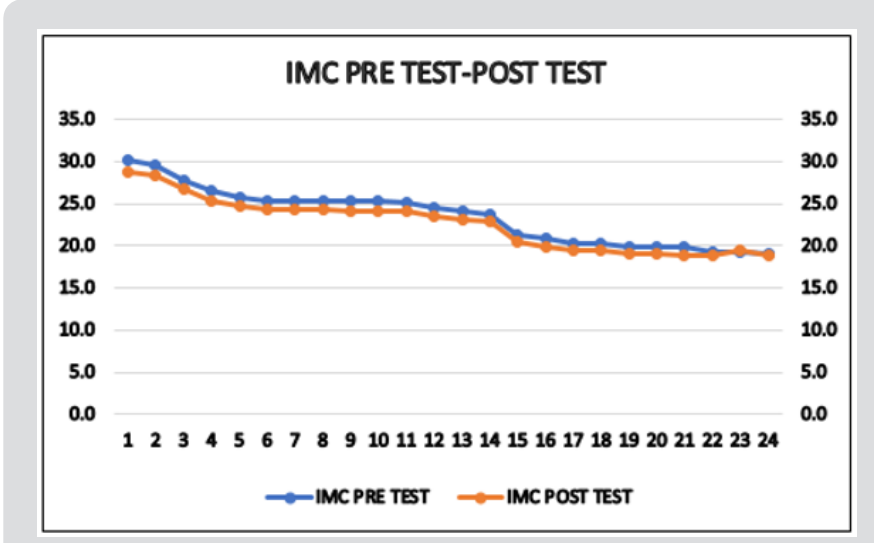

Source: Research data.

Figure 1: IMC Pre Test-Post Test.

Table 1: Test T Students.

\begin{tabular}{|c|c|c|}
\hline & Variable 1 & Variable 2 \\
\hline Half & 23,51 & 22,6033333 \\
\hline Variance & 11,35004348 & 9,69302319 \\
\hline Observations & 24 & 24 \\
\hline Pearson's correlation coefficient & 0,997460514 & \\
\hline Hypothetical difference of the means & 0 & \\
\hline Degrees of freedom & 23 & \\
\hline Statistic t & 12,89687208 & \\
\hline P (T < = t) a tail & $2,58788 \mathrm{E}-12$ & \\
\hline Critical value of t (one tail) & 1,713871528 & \\
\hline P $(\mathrm{T}<=\mathrm{t}$ ) two tails & $5,17576 \mathrm{E}-12$ & \\
\hline Critical value of t (two tails) & 2,06865761 & \\
\hline
\end{tabular}

Source: Research data. 
After the work done of a training of 6 months every day from Monday to Friday the following results were achieved The work was carried out with a total of 25 among the boys and girls of the sixth year of basic education, of which 10 are in the range considered as obesity, 4 in the range of overweight, 6 in the range considered normal and 5 students who are in the low weight range. It can be added that in this age, low weight can be considered normal. This is due to the incessant activity of some children (Figure 2).

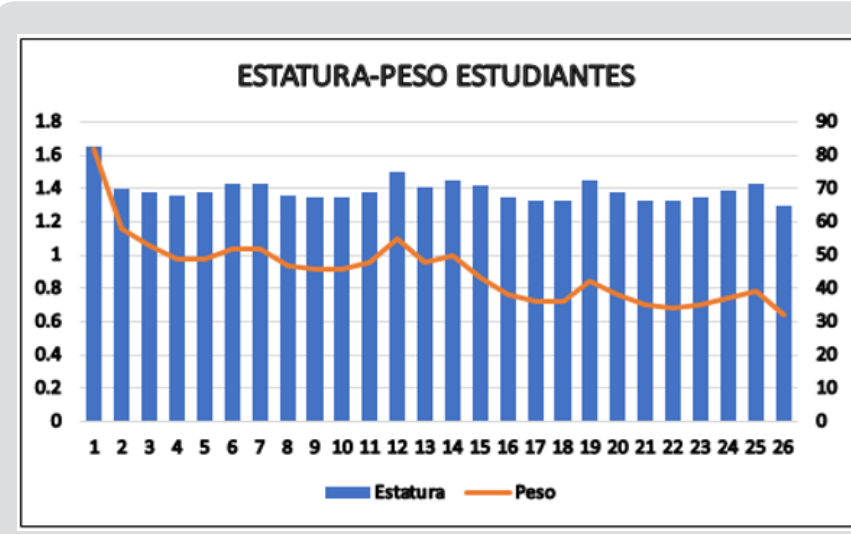

Source: Research data.

Figure 2: Height-Weight Students.

When comparing with the data obtained with the students of the 7 th year, it can be seen that the difference is even wider. The results with this basic year are: Among the most representative results is that of 25 students of which 10 are in the range considered as obesity, 4 in the range of overweight, 6 in the range considered normal and 5 students who are found in the low weight range [310].

\section{Conclusion}

a) $34 \%$ of students respond that their favorite sport is soccer, $22 \%$ basketball, 5\% karate and 28\% other sports; Teachers consider that students prefer basketball as their favorite sport, as representatives state that soccer is the preferred sport.

b) Sports practice has had a positive impact on the academic performance of students.

\section{ISSN: 2574-1241}

DOI: 10.26717.BJSTR.2019.14.002551

Vinicio Bonilla Carrión. Biomed J Sci \& Tech Res

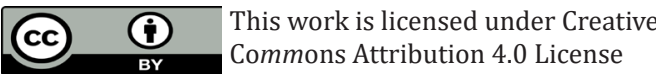

Submission Link: https://biomedres.us/submit-manuscript.php c) Comparing the grades of the previous year with those of this year, it is considered that there has been a change and this has been positive for the students.

d) According to the parents and teachers, the directed sports practice has positively influenced the academic performance of the students, and during the training period the fulfillment of the school tasks has been in good form fulfilled by the students.

e) Both students, representatives and teachers indicate that the behavior of students in the classroom after practicing sports is acceptable to a large extent, therefore sports practice has a positive influence on the behavior of students in the classroom.

f) All the people interviewed indicate that the students have fun with sports and are more predisposed for the study.

g) The results obtained indicate that students should practice sports in institutions.

h) Most respondents report that students should practice sports in the morning because they are predisposed to studying during the day.

\section{References}

1. González Haro C (2009) Cineanthropometry. Editorial Funiber, Madrid, Spain.

2. Córdova Martínez D, Terrados Cepeda D, Del Valle Solto D, Villa Vicente D (2011) The Physical Activity for Health in Different Diseases, Funiber.

3. Bompa T (2003) Theory and Methodology of training. Hispano Europea SA, Barcelona, Spain.

4. Bressiani G (2008) Physical activity and exercise in health. Editorial Funiber, Madrid, Spain.

5. Garatachea Vallejo D, Aznar Laín D (2011) Control and prescription of physical activity, Funiber.

6. Garcés E, Ortín F, Olmedilla A (2009) Psychosocial Aspects of Physical Action for Health. Editorial Funiber, Madrid, Spain.

7. Gottau G (2008) Diseases, Hypertension in Adolescents.

8. Lantigua I (2006) Adolescent athletes "behave" better, The World is Health.

9. Redondo J, Abella C (2008) Sports Planning. Editorial Funiber, Madrid, Spain.

10. Vallejo J (1990) The therapy of running. Guayaquil, Ecuador: Offset GRABA.

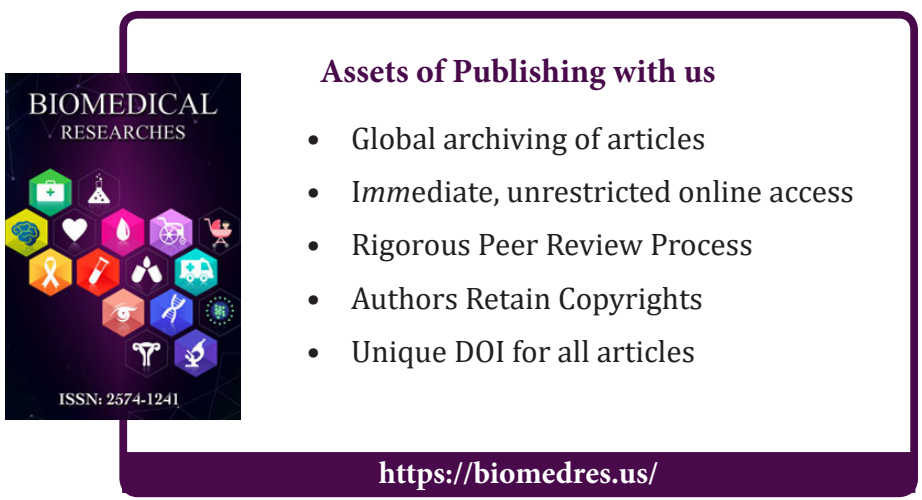

